\title{
MINERAL COMPOSITION OF HERBY CHEESE PRODUCED FROM RAW AND PASTEURIZED MILK
}

\author{
KÖSE, Ş. ${ }^{*}$ - OCAK, E. \\ Department of Food Engineering, Faculty of Engineering, Van Yuzuncu Yil University, 65080 \\ Van, Turkey \\ *Corresponding author \\ e-mail: senolkose28@gmail.com; phone: +90-432-225-1024; fax: 90-432-225-1730
}

(Received 27 $7^{\text {th }}$ Feb 2019; accepted 10 $10^{\text {th }}$ Apr 2019)

\begin{abstract}
In this study, the effects of sirmo (Allium vineale L.), mendi (Chaerophyllum macropodum Boiss.) and siyabo (Ferula rigidula DC.) on mineral compositions of herby cheese produced from raw and pasteurized milk in brine and vacuum package during 90 days ripening were determined. Macroelements ( $\mathrm{Ca}, \mathrm{Mg}, \mathrm{Na}, \mathrm{K})$ and micro elements ( $\mathrm{Fe}, \mathrm{Zn}, \mathrm{Mn}$ ) concentration of herby cheese samples were examined by Inductively Coupled Plasma-Optical Emission Spectrometer (ICP-OES). It was determined that the mineral concentration was changed from highest to lowest $\mathrm{Na}>\mathrm{Ca}>\mathrm{K}>\mathrm{Mg}>\mathrm{Zn}>\mathrm{Fe}>\mathrm{Mn}$ in the herby cheese. The highest mean concentration of $\mathrm{Na}$ was found in Sirmo added cheeses manufactured from raw milk in brine on the second day of ripening and the lowest mean concentration of Mn was found in Sirmo added cheeses produced from pasteurized milk in brine at the end of 90 days. $\mathrm{Na}, \mathrm{Ca}, \mathrm{K}, \mathrm{Mg}, \mathrm{Zn}, \mathrm{Fe}$ and $\mathrm{Mn}$ content of cheeses in brine and vacuum package decreased during ripening period.
\end{abstract}

Keywords: herbs, mineral content, ripening period, packaging type

\section{Introduction}

Herby cheese is one of the most popular cheeses traditionally produced from raw sheep's milk in the Eastern and South eastern region of Turkey (Tarakci and Temiz, 2009) particularly around Van province. If sheep milk is not available, sheep milk can be mixed with goat and cow milk for cheese production (Tarakci et al., 2004). Herby cheese variety has a salty taste, semi hard texture and is produced in small families (Andic et al., 2010, 2015; Tuncturk et al., 2014) between May and June (Tarakci and Temiz, 2009). It has been traditionally produced more than 200 years in Van and Eastern region of Turkey (Tarakci and Akyuz, 2009). But nowadays the cheeses are also manufactured commercially using pasteurized milk, starter culture in some dairies (in Van or other parts of Turkey). Almost 12 kinds of herbs are used for the production of Herby cheese. However, the most preferred herbs are sirmo (Allium vineale L.), mendi (Chaerophyllum macropodum Boiss.) and siyabo (Ferula rigidula DC.) (Kose, 2015). The herbs ensure the cheese its characteristic aroma/flavour and appearance, but also prolong the shelf-life of cheese (Hayaloglu and Fox, 2008).

There are many macro and micro minerals in milk and dairy products. These minerals are very important both in terms of nutritional physiology and physical stability of the cows and the catalytic effects of milk and dairy products (Ocak and Kose, 2015). The mineral content of cheese sample depends on various factors such as feeding, genetic, lactation period, geographical area of milk production, environmental conditions, lack of a standart technique in cheese production and possible contamination from the equipment during the cheese production (Altun and Kose, 2016). 
There are many studies related to mineral content of herby cheese. The concentration of cheese samples were found by Tarakci and Kucukoner (2008) as 313.7, 552.6, 2606, $12.70 \mathrm{mg} / 100 \mathrm{~g}$ for $\mathrm{Ca}, \mathrm{P}, \mathrm{Na}, \mathrm{Mg}$, respectively. Heavy metals (ppm) were determined as 41.79, 33.99, 6.25, $2.05 \mathrm{mg} / \mathrm{kg}$ for $\mathrm{Fe}, \mathrm{Zn}, \mathrm{Cu}$ and $\mathrm{Mn}$, respectively. Tarakci et al. (2005) determined the mineral contents of herby cheese samples (mg/100 g) as 289.49, 499.54, 2798.61, 3.20, 31.93, 46.07, 5.95 for $\mathrm{Ca}, \mathrm{P}$, $\mathrm{Na}, \mathrm{Mg}, \mathrm{Zn}, \mathrm{Fe}$ and $\mathrm{Cu}$, respectively. The same study, $\mathrm{Mn}, \mathrm{Cr}, \mathrm{Co}, \mathrm{Cd}$ and $\mathrm{Ni}$ concentrations (ppm) were determined as 2.18, 0.23, 0.29, 0.22 and 0.19, respectively. Ocak and Kose (2015) determined $\mathrm{Ca}, \mathrm{K}, \mathrm{Mg}, \mathrm{Cu}, \mathrm{Mn}, \mathrm{Fe}$ and $\mathrm{Zn}$ content of 26 Herby cheese samples obtained from retail markets in Van. They determined the concentration ranges in the cheese samples as 268.7-678.7, 84.6$163.2,26.3-80.8, \mathrm{mg} / 100 \mathrm{~g}, 0.38-2.23,8.13-25.94,0.29-2.60,3.14-29.25 \mathrm{mg} / \mathrm{kg}$ for $\mathrm{Ca}, \mathrm{K}, \mathrm{Mg}, \mathrm{Mn}, \mathrm{Zn}, \mathrm{Cu}$ and Fe, respectively. Sagun et al. (2005) determined mineral contents of herby cheeses during ripening (90 days). It was determined that $\mathrm{Ca}, \mathrm{Mg}$, $\mathrm{Fe}, \mathrm{Zn}, \mathrm{Mn}, \mathrm{Ni}$ and $\mathrm{Cr}$ contents decreased $(\mathrm{P}<0.05)$, the $\mathrm{Na}$ content of cheeses increased $(\mathrm{P}<0.05)$.

Many studies were performed to determine mineral contents of herby cheese samples but there is no study focusing on the effect of packaging, ripening and different herbs on macro and micro element accumulations in herby cheese. Therefore, the purpose of this investigation was to determine the effect of packaging, ripening and different herbs on the mineral content of herby cheese produced from raw and pasteurized milk during ripening.

\section{Materials and methods}

\section{Production of herby cheese}

Two different manufacturing methods were applied for production of herby cheese samples.

In the first method, milk and herbs were not pasteurized and the starter culture was not used. The pickled forms of the most preferred three local herbs such as Sirmo (Allium vineale L.), Mendi (Chaerophyllum macropodum Boiss.) and Siyabo (Ferula rigidula DC.) were separately and mixed used for cheese production. The raw milk is filtered through a cloth filter and heated to $32{ }^{\circ} \mathrm{C}$ and is then coagulated by using commercial rennet (Mayasan company, İstanbul, Turkey) for $1 \mathrm{~h}$. After coagulation, the curd is cut into small cubes. The curd partly drained and divided into 5 groups (A1 control group, A2 sirmo-added groups, A3 mendi-added groups, A4 siyaboadded groups, A5 sirmo, mendi and siyabo mixture added groups). Then the pickled herbs were added at levels of $2 \mathrm{~kg}$ to the curd obtained from $100 \mathrm{~kg}$ of milk. The mixture of curd and herbs were pressed with a heavy object for $3 \mathrm{~h}$ and then cut into blocks $(7 \times 7 \times 2 \mathrm{~cm})$. The cheese blocks were placed in glass jars which are salted with $14 \%$ brine and held $12 \mathrm{~h}$. At the end of this time, some of cheeses were continue to ripened in glass jars which were salted with $14 \%$ brine concentration, a portion of cheese were vacuum packed in plastic bags and were ripened at $4{ }^{\circ} \mathrm{C}$ for 90 days.

In the second method, the raw milk was filtered and pasteurized at $65{ }^{\circ} \mathrm{C}$ for 30 min. Then milk was cooled to $32{ }^{\circ} \mathrm{C}, \mathrm{CaCl}_{2}$ and starter culture (Streptococcus thermophilus, Lactococcus lactis subsp. lactis and Lactococcus lactis subsp. cremoris) were added at the ratios of 0.02 and $1.5 \%$, respectively. Then, milk was 
coagulated with rennet enzyme. After coagulation, the curd was cut into small pieces. The curd partly drained and divided into 5 groups as in the first method (B1 control group, B2 sirmo-added groups, B3 mendi-added groups, B4 siyabo-added groups, B5 sirmo, mendi and siyabo mixture added groups). The pasteurized herbs (at $95{ }^{\circ} \mathrm{C}$ for $5 \mathrm{~min}$ ) were added into the curd and mixed well. Then the mixture of curd and herbs were pressed for $3 \mathrm{~h}$ to remove the whey sufficiently and the curd was cut into the blocks $(7 \times 7 \times 2 \mathrm{~cm})$. The cheese blocks were placed in glass jars which were salted with $14 \%$ brine and held $12 \mathrm{~h}$. At the end of this time, some of cheeses were continue to ripened in glass jars which were salted with $14 \%$ brine concentration, a portion of cheeses were vacuum packaged in plastic bags and were ripened at $4{ }^{\circ} \mathrm{C}$ for 90 days. Mineral compositions of samples were analyzed 2, 30, 60, 90 days of storage at $4{ }^{\circ} \mathrm{C}$. Each assay was performed in triplicate.

\section{Mineral analysis}

The cheese samples were burned by using dry ashing method in a ash furnace at $550{ }^{\circ} \mathrm{C}$ for $16 \mathrm{~h}$. Before the samples were put in the ash furnace, they were dried in the oven at $105^{\circ} \mathrm{C}$ for $1 \mathrm{~h}$ (IDF, 1992). The ash was dissolved with $5 \mathrm{ml}$ nitric acid (1 $\mathrm{N} \mathrm{HNO}_{3}$ ) on heating plate and were filtered using (Whatman no: 41) filter paper. Then the solution was diluted with $1 \mathrm{~N} \mathrm{HNO3}$ and completed in $50 \mathrm{ml}$ with $1 \mathrm{~N}$ $\mathrm{HNO}_{3}$. The concentrations of $\mathrm{Ca}, \mathrm{Mg}, \mathrm{K}, \mathrm{Na}, \mathrm{Zn}, \mathrm{Fe}$ and $\mathrm{Mn}$ of the samples were measured by Inductively Coupled Plasma-Optical Emission Spectrometer (ICP-OES) (Thermo Scientific ICAP 6300 DUO, England) at 317.93, 279.55, 766.49, 588.99, 213.86, 259.94, and 257.61 respectively. Also, blank samples were prepared for use in calculations.

\section{Statistical analysis}

Concentrations of cheese samples were recorded as means \pm standard deviation of triplicate measurements. In the analysis of the data, SPSS (V.20) package program was used. A general linear model (GLM) analysis was used to determine the differences between the groups and the Duncan multiple comparison test was used to determine differences among the three groups. Also, for comparison of two independent groups, t test was used.

\section{Results and discussion}

The mineral content of herby cheese manufactured from raw and pasteurized milk in vacuum and brine are given Tables 1-7.

\section{Calcium}

The calcium concentration of vacuum and brine herby cheese samples varied from $2362.47-4820.35 \mathrm{mg} / \mathrm{kg}$. Our results were accordance with findings of Ocak and Kose (2015), Mendil (2006) and higher than the values of determined by Ozlu et al. (2012).

As seen Table 1, the calcium content of cheese samples decreased from the 2 th until 90 th days. The Ca loss of cheeses in brine were higher than in vacuum packaged, due to salt uptake from brine during the ripening period. Transport of $\mathrm{Na}^{+}$ and $\mathrm{Cl}^{-}$ions from brine into the cheese, as a consequence of the osmotic pressure 
difference between the brine and the moisture of the cheese. Depending on the amount of lactose and minerals in it, moisture of cheese has a certain osmotic pressure. The osmotic pressure of the brine is higher due to the excess of salt. For this reason, the pressure difference between the brine and cheese causes diffusion. When a moulded cheese is placed in brine, diffusions of $\mathrm{Na}^{+}$and $\mathrm{Cl}^{-}$ions from brine into the cheese and diffusions of $\mathrm{H}_{2} \mathrm{O}$, lactose, serum protein, various mineral substances such as $\mathrm{Ca}, \mathrm{Mg}, \mathrm{K}, \mathrm{P}$ from cheese into the brine until the osmotic pressure between both phases is equalized. The amount of water lost is about twice the amount of salt obtained. For this reason, the weight of cheese decreases during the storage period (Gider, 2006). As long as the ripening period is long, transport of $\mathrm{Na}^{+}$and $\mathrm{Cl}^{-}$ ions from brine into the cheese increases with very rapid salt uptake in the beginning but decreases during the storage periods (Guinee and Fox, 1986). Similarly, in our study the $\mathrm{Ca}$ concentrations of the herby cheeses in brine rapidly decreased from the 2nd until the 30th day of storage but the loss of Ca has decreased from the 30th until the 90th days. The reason for this explained by the some researchers as a reduction of $\mathrm{NaCl}$ concentration difference between brine and cheese moisture (Guinee and Fox, 1986; Gider, 2006).

Table 1. The effects of Sirmo, Mendi and Siyabo on Ca concentrations of herby cheese produced from pasteurized and raw milk in brine and vacuum package during ripening

\begin{tabular}{|c|c|c|c|c|c|c|}
\hline \multirow{2}{*}{$\begin{array}{l}\text { Packaging } \\
\text { type }\end{array}$} & \multirow{2}{*}{$\begin{array}{l}\text { Storage } \\
\text { time }\end{array}$} & \multicolumn{5}{|c|}{ Treatment } \\
\hline & & A1 & A2 & A3 & A4 & A5 \\
\hline \multirow{4}{*}{ Brine } & 2 & $4650.72 \pm 161.53^{\mathrm{bAB}}$ & $4184.15 \pm 170.48^{\mathrm{cAB}}$ & $4532.91 \pm 259.5^{\mathrm{bAB}}$ & $4820.35 \pm 407.42^{\mathrm{bB}}$ & $4066.94 \pm 181.56^{\mathrm{cA}}$ \\
\hline & 30 & $3556.06 \pm 83.64^{\mathrm{aAB} \# \alpha}$ & $3635.36 \pm 73.11 b^{\mathrm{AB} \#}$ & $3570.58 \pm 141.42^{\mathrm{aAB} \#}$ & $3152.73 \pm 0.28^{\mathrm{aA \#}}$ & $3783.52 \pm 392.8 b^{c B}$ \\
\hline & 60 & $3314.44 \pm 186.85^{\mathrm{aA \#}}$ & $3570.53 \pm 114.2^{\mathrm{abA}}$ & $3280.50 \pm 0.71^{\mathrm{aA}}$ & $3399.15 \pm 131.61^{\mathrm{aA}}$ & $3399.96 \pm 119.32^{\mathrm{bA}}$ \\
\hline & 90 & $3242.70 \pm 181.08^{\mathrm{aB} \#}$ & $3209.54 \pm 189.66^{\mathrm{aB} \#}$ & $3265.66 \pm 225.17^{\mathrm{aB}}$ & $3204.24 \pm 91.51^{\mathrm{aB}}$ & $2588.47 \pm 100.07^{\mathrm{aA} \#}$ \\
\hline \multirow{4}{*}{ Vacuum } & 2 & $4650.72 \pm 161.53^{\mathrm{aAB}}$ & $4184.15 \pm 170.48^{\mathrm{bAB}}$ & $4532.91 \pm 259.5^{\mathrm{bAB}}$ & $4820.35 \pm 407.42^{\mathrm{bB}}$ & $4066.94 \pm 181.56^{\mathrm{aA}}$ \\
\hline & 30 & $4525.97 \pm 179.03^{\mathrm{aBC}}$ & $4114.33 \pm 7.21^{\mathrm{abA} \alpha}$ & $4456.70 \pm 0.00^{\mathrm{bB} \alpha}$ & $4726.87 \pm 0.00^{\mathrm{bC}}$ & $3929.99 \pm 16.67^{\mathrm{abA} \alpha}$ \\
\hline & 60 & $4384.07 \pm 97.56^{\mathrm{aA}}$ & $4068.84 \pm 11.31^{\mathrm{abB}}$ & $4216.63 \pm 141.42^{\mathrm{abBC}}$ & $4329.94 \pm 12.73^{\mathrm{abC}}$ & $3834.68 \pm 22.63^{\mathrm{abA} \alpha}$ \\
\hline & 90 & $4226.46 \pm 166.78^{\mathrm{aB} \alpha}$ & $3886.58 \pm 35.54^{\mathrm{aA}}$ & $3810.42 \pm 14.14^{\mathrm{aA}}$ & $3968.64 \pm 2.83^{\mathrm{aA} \alpha}$ & $3788.74 \pm 0.14^{\mathrm{aA} \alpha}$ \\
\hline & & B1 & B2 & B3 & B4 & B5 \\
\hline \multirow{4}{*}{ Brine } & 2 & $4502.60 \pm 407.15^{\mathrm{bA}}$ & $4365.97 \pm 564.35^{\mathrm{cA}}$ & $4285.91 \pm 482.4^{\mathrm{bA}}$ & $4384.37 \pm 296.76^{\mathrm{cA}}$ & $4271.32 \pm 54.28^{\mathrm{cA}}$ \\
\hline & 30 & $3058.23 \pm 14.14^{\mathrm{aA \#}}$ & $3523.21 \pm 32.82^{\mathrm{bcC} \#}$ & $3188.32 \pm 64.86^{\mathrm{aAB} \#}$ & $3369.00 \pm 141.42^{\mathrm{bB}}$ & $3252.86 \pm 141.42^{\mathrm{bAB}}$ \\
\hline & 60 & $2910.64 \pm 141.03^{\mathrm{aA}}$ & $3448.22 \pm 31.19^{\mathrm{bC} \#}$ & $3057.73 \pm 132.72^{\mathrm{aAB}}$ & $3055.33 \pm 70.71^{\mathrm{abAB} \#}$ & $3225.56 \pm 141.42^{\mathrm{bB}}$ \\
\hline & 90 & $2942.95 \pm 2.83^{\mathrm{aB}}$ & $2362.47 \pm 282.84^{\mathrm{aA \#}}$ & $2833.74 \pm 4.24^{\mathrm{aB}}$ & $2876.38 \pm 18.74^{\mathrm{aB \#}}$ & $2855.01 \pm 141.42^{\mathrm{aB} \#}$ \\
\hline \multirow{4}{*}{ Vacuum } & 2 & $4502.60 \pm 407.15^{\mathrm{cA}}$ & $4365.97 \pm 564.35^{\mathrm{aA}}$ & $4285.91 \pm 482.4^{\mathrm{aA}}$ & $4384.37 \pm 296.76^{\mathrm{aA}}$ & $4271.32 \pm 54.28^{\mathrm{bA}}$ \\
\hline & 30 & $4179.68 \pm 77.32^{\mathrm{bcA}}$ & $4256.25 \pm 0.00^{\mathrm{aA}}$ & $4127.20 \pm 24.37^{\mathrm{aA}}$ & $4224.23 \pm 349.78^{\mathrm{aA}}$ & $4204.50 \pm 0.28^{\mathrm{bA}}$ \\
\hline & 60 & $3739.81 \pm 0.14^{\mathrm{abA}}$ & $4142.80 \pm 2.83^{\mathrm{aD}}$ & $3915.40 \pm 21.21^{\mathrm{aB}}$ & $3985.59 \pm 7.07^{\mathrm{aC}}$ & $4189.15 \pm 12.73^{\mathrm{bE}}$ \\
\hline & 90 & $3200.25 \pm 238.5^{\mathrm{aA}}$ & $4116.04 \pm 203.92^{\mathrm{aB}}$ & $3895.31 \pm 2.83^{\mathrm{aB}}$ & $3853.78 \pm 4.24^{\mathrm{aB}}$ & $3963.99 \pm 40.9^{\mathrm{aB}}$ \\
\hline
\end{tabular}

Data values are expressed as means \pm standard deviation. Values in the same column followed by a different letters $(\mathrm{a}-\mathrm{c})$ are significantly different $(P<0.05)$. Values in the same row followed by a different letters $($ A-C) are significantly different $(P<0.05)$. Values in the same column showed different letter $(\alpha)$ between different treatments in the same day and package $(P<0.05)$. Values in the same column showed different letter (\#) between different packages in the same day and package $(P<0.05)$

A1: control cheese manufactured from raw milk, A2: sirmo-added cheese manufactured from raw milk, A3: mendi-added cheese manufactured from raw milk, A4: siyabo-added cheese manufactured from raw milk, A5: sirmo, mendi and siyabo mixture added cheese manufactured from raw milk, B1: control cheese manufactured from pasteurized milk, B2: sirmo-added cheese manufactured from pasteurized milk B3: mendi-added cheese manufactured from pasteurized milk, B4: siyabo-added cheese manufactured from pasteurized milk, B5: sirmo, mendi and siyabo mixture added cheese manufactured from pasteurized milk 


\section{Magnesium}

It was determined that the magnesium content of samples ranged from 114.79$282.30 \mathrm{mg} / \mathrm{kg}$. Therefore, the level of magnesium in the vacuum cheeses were higher than in brine cheeses. These results were agreement with findings obtained by Cetinkaya et al. (2016) as 111.20-214 mg/kg for Camibogazı and Ozlu et al. (2012) as $65.83-210.09 \mathrm{mg} / \mathrm{kg}$ for Kasar cheese but higher than the value determined by Kurdar et al. (2013) as $49.62 \mathrm{mg} / \mathrm{kg}$ for Akçakatik and Kirdar et al. (2015) as 72.6 to 88.9 for Karg1 Tulum cheese.

The magnesium concentration of herby cheese decreased throughout the storage period similar to that $\mathrm{Ca}$ content. The possible reason for this situation, $70 \%$ of the $\mathrm{Mg}$ is in soluble form (Ocak and Kose, 2015) so transport of $\mathrm{Mg}$ from cheese into the brine until the osmotic pressure between brine and cheese phase is equalized during the storage period.

At the end of the ripening period, Siyabo added herby cheese (A4 and B4) in vacuum packaged had higher $\mathrm{Mg}$ values. This is probably due to the high $\mathrm{Mg}$ content of Siyabo in comparison to Sirmo and Mendi and loss of $\mathrm{Mg}$ in brine cheeses were higher than vacuum packaged.

Table 2. The effects of Sirmo, Mendi and Siyabo on Mg concentrations of herby cheese produced from pasteurized and raw milk in brine and vacuum package during ripening

\begin{tabular}{|c|c|c|c|c|c|c|}
\hline \multirow{2}{*}{\multicolumn{2}{|c|}{$\begin{array}{l}\text { Packaging Storage } \\
\text { type time }\end{array}$}} & \multicolumn{5}{|c|}{ Treatment } \\
\hline & & A1 & A2 & $\mathbf{A 3}$ & A4 & A5 \\
\hline \multirow{4}{*}{ Brine } & 2 & $282.30 \pm 0.94^{\mathrm{cC}}$ & $250.81 \pm 8.3^{\mathrm{cAB}}$ & $268.49 \pm 7.54^{\mathrm{cBC}}$ & $280.80 \pm 21.01^{\mathrm{bBC}}$ & $226.08 \pm 10.71^{\mathrm{cA}}$ \\
\hline & 30 & $157.84 \pm 7.21^{\mathrm{bA \#}}$ & $165.45 \pm 3.13^{\mathrm{bA \#}}$ & $166.85 \pm 2.44^{\mathrm{bA}}$ & $152.74 \pm 3.68^{\mathrm{aA}}$ & $172.62 \pm 16.38^{\mathrm{bA}}$ \\
\hline & 60 & $141.58 \pm 4.84^{\mathrm{aA} \#}$ & $148.16 \pm 6.35^{\mathrm{bAB} \#}$ & $142.99 \pm 1.85^{\mathrm{aAB} \#}$ & $153.79 \pm 4.64^{\mathrm{aB \#}}$ & $149.14 \pm 3.45^{\mathrm{abAB} \#}$ \\
\hline & 90 & $137.35 \pm 0.49^{\mathrm{aAB} \#}$ & $123.30 \pm 10.65^{\mathrm{aA}}$ & $139.62 \pm 7.94^{\mathrm{aAB}}$ & $140.02 \pm 2.97^{\mathrm{aB} \#}$ & $126.51 \pm 1.35^{\mathrm{aAB}}$ \\
\hline \multirow{4}{*}{ Vacuum } & 2 & $282.30 \pm 0.94^{\mathrm{cC}}$ & $250.81 \pm 8.3^{\mathrm{bAB}}$ & $268.49 \pm 7.54^{\mathrm{bBC}}$ & $280.80 \pm 21.01^{\mathrm{bBC}}$ & $226.08 \pm 10.71^{\mathrm{aA}}$ \\
\hline & 30 & $216.65 \pm 8.85^{\mathrm{bA}}$ & $241.66 \pm 13.08^{\mathrm{bA}}$ & $244.16 \pm 36.23^{\mathrm{bA}}$ & $241.94 \pm 27^{\mathrm{abA}}$ & $220.96 \pm 3.15^{\mathrm{aA}}$ \\
\hline & 60 & $203.93 \pm 1.07^{\mathrm{abB}}$ & $207.00 \pm 1.46^{\mathrm{aB}}$ & $186.47 \pm 2.83^{\mathrm{aA}}$ & $203.93 \pm 9.02^{\mathrm{aB}}$ & $207.90 \pm 7.52^{\mathrm{aB}}$ \\
\hline & 90 & $191.35 \pm 2.79^{\mathrm{aA}}$ & $197.06 \pm 0.33^{\mathrm{aA}}$ & $178.28 \pm 0.81^{\mathrm{aA}}$ & $197.67 \pm 7.18^{\mathrm{aA}}$ & $193.57 \pm 20.6^{\mathrm{aA}}$ \\
\hline & & B1 & B2 & B3 & B4 & B5 \\
\hline \multirow{4}{*}{ Brine } & 2 & $251.56 \pm 26.04^{\mathrm{bA}}$ & $252.58 \pm 33.79^{\mathrm{bA}}$ & $246.22 \pm 24.08^{\mathrm{bA}}$ & $238.89 \pm 6.82^{\mathrm{cA}}$ & $239.63 \pm 4.74^{\mathrm{cA}}$ \\
\hline & 30 & $161.33 \pm 5.54^{\mathrm{aC} \#}$ & $162.02 \pm 1.54^{\mathrm{aC}}$ & $152.00 \pm 0.44^{\mathrm{aB}}$ & $163.62 \pm 0.43^{\mathrm{bC}}$ & $142.27 \pm 3.75^{\mathrm{bA \#}}$ \\
\hline & 60 & $140.78 \pm 10.85^{\mathrm{aAB}}$ & $151.76 \pm 1.08^{\mathrm{aB} \#}$ & $137.21 \pm 3.03^{\mathrm{aAB} \#}$ & $135.41 \pm 6.88^{\mathrm{aA \#}}$ & $137.10 \pm 2.16^{\mathrm{abAB} \#}$ \\
\hline & 90 & $135.72 \pm 0.33^{\mathrm{aA}}$ & $114.79 \pm 40.06^{\mathrm{aA}}$ & $130.97 \pm 0.98^{\mathrm{aA}}$ & $134.35 \pm 1.85^{\mathrm{aA}}$ & $128.72 \pm 2.31^{\mathrm{aA \#}}$ \\
\hline \multirow{4}{*}{ Vacuum } & 2 & $251.56 \pm 26.04^{\mathrm{bA}}$ & $252.58 \pm 33.79^{\mathrm{aA}}$ & $246.22 \pm 24.08^{\mathrm{cA}}$ & $238.89 \pm 6.82^{\mathrm{bA}}$ & $239.63 \pm 4.74^{\mathrm{bA}}$ \\
\hline & 30 & $217.14 \pm 2.32^{\mathrm{abA}}$ & $244.17 \pm 26.86^{\mathrm{aA}}$ & $238.67 \pm 10.67^{\mathrm{bcA}}$ & $219.90 \pm 7.94^{\mathrm{abA}}$ & $218.36 \pm 11.14^{\mathrm{aA}}$ \\
\hline & 60 & $192.20 \pm 5.33^{\mathrm{aA}}$ & $211.66 \pm 1.81^{\mathrm{aB}}$ & $203.66 \pm 7.95^{\mathrm{abAB}}$ & $211.87 \pm 2.64^{\mathrm{aB}}$ & $211.70 \pm 1.82^{\mathrm{aB}}$ \\
\hline & 90 & $184.31 \pm 15.04^{\mathrm{aA}}$ & $188.74 \pm 21.67^{\mathrm{aA}}$ & $193.05 \pm 10.34^{\mathrm{aA}}$ & $203.33 \pm 13.92^{\mathrm{aA}}$ & $203.28 \pm 6.34^{\mathrm{aA}}$ \\
\hline
\end{tabular}

Data values are expressed as means \pm standard deviation. Values in the same column followed by a different letters $(\mathrm{a}-\mathrm{c})$ are significantly different $(P<0.05)$. Values in the same row followed by a different letters $($ A-C) are significantly different $(P<0.05)$. Values in the same column showed different letter $(\alpha)$ between different treatments in the same day and package $(P<0.05)$. Values in the same column showed different letter (\#) between different packages in the same day and package $(P<0.05)$

A1: control cheese manufactured from raw milk, A2: sirmo-added cheese manufactured from raw milk, A3: mendi-added cheese manufactured from raw milk, A4: siyabo-added cheese manufactured from raw milk, A5: sirmo, mendi and siyabo mixture added cheese manufactured from raw milk, B1: control cheese manufactured from pasteurized milk, B2: sirmo-added cheese manufactured from pasteurized milk B3: mendi-added cheese manufactured from pasteurized milk, B4: siyabo-added cheese manufactured from pasteurized milk, B5: sirmo, mendi and siyabo mixture added cheese manufactured from pasteurized milk 


\section{Sodium}

The 2005 Dietary Guidelines for Americans recommends that healthy adults limit consumption of sodium $2300 \mathrm{mg} / \mathrm{d}(5.84 \mathrm{~g}$ of NaCI or about 1 teaspoon of table salt) and hypertensive patients and the older adults should not take more than $1500 \mathrm{mg}$ of sodium per day (Agarwal et al., 2011). The main source of sodium in diet is $\mathrm{NaCl}$, most of salt comes from commercial food in the improved countries. Sodium is important for regulation of blood and osmotic pressure, transport of water into and out of cells and transmission of nerve cell impulses (Cruz et al., 2011). However, excess intake of Na causes high blood pressure and other chronic diseases (Felicio et al., 2013). Another symptom that may be caused by high intake of sodium is the interference in bioavailability of calcium due to the increase in the renal excretion of this mineral. According to predictive equations, it is believed that urinary excretion of calcium will increase by $30-40 \mathrm{mg}$, for each $2 \mathrm{~g}$ of sodium consumed. However, if the intake of sodium is below $2.4 \mathrm{~g}$ per day, there will be no negative effect on the bones (Cruz et al., 2011).

Table 3. The effects of Sirmo, Mendi and Siyabo on Na concentrations of herby cheese produced from pasteurized and raw milk in brine and vacuum package during ripening

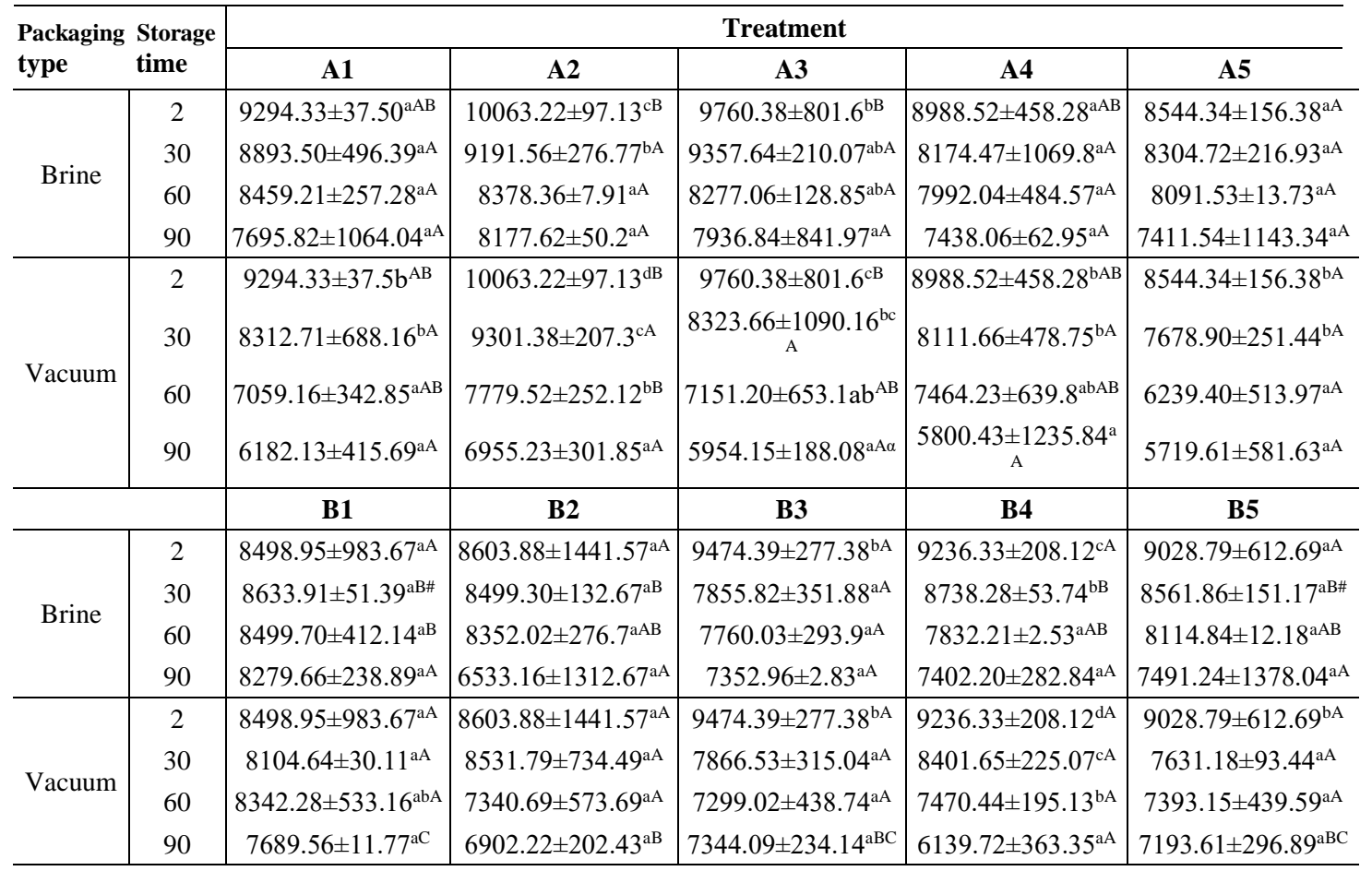

Data values are expressed as means \pm standard deviation. Values in the same column followed by adifferent letters $(\mathrm{a}-\mathrm{c})$ are significantly different $(P<0.05)$. Values in the same row followed by adifferent letters $($ A-C) are significantly different $(P<0.05)$. Values in the same column showed different letter $(\alpha)$ between different treatments in the same day and package $(P<0.05)$. Values in the same column showed different letter (\#) between different packages in the same day and package $(P<0.05)$

A1: control cheese manufactured from raw milk, A2: sirmo-added cheese manufactured from raw milk, A3: mendi-added cheese manufactured from raw milk, A4: siyabo-added cheese manufactured from raw milk, A5: sirmo, mendi and siyabo mixture added cheese manufactured from raw milk, B1: control cheese manufactured from pasteurized milk, B2: sirmo-added cheese manufactured from pasteurized milk B3: mendi-added cheese manufactured from pasteurized milk, B4: siyabo-added cheese manufactured from pasteurized milk, B5: sirmo, mendi and siyabo mixture added cheese manufactured from pasteurized milk 
The sodium content of cheese samples ranged from 5719.61 to $10063.22 \mathrm{mg} / \mathrm{kg}$. It has been exhibited that the sodium levels suggested for a healthy person can be met by consuming about $250 \mathrm{~g}$ of Herby cheese. Sodium in herby cheese is due to milk naturally contain some sodium as well as due to added salt and pickled herbs. Our results were similar with findings obtained by Cetinkaya et al. (2016) as 4852.5$10520 \mathrm{mg} / \mathrm{kg}$ for Camiboğazı, by Holland et al. (1995) as $700 \mathrm{mg} / 100 \mathrm{~g}$ for Brie cheese, lower than the value determined by Tarakci and Kucukoner (2008) as $2606 \mathrm{mg} / 100 \mathrm{~g}$ for herby cheese and higher than the value determined by Holland et al. (1995) as $380 \mathrm{mg} / 100 \mathrm{~g}$ for Cottage cheese, by Felicio et al. (2013) as 574.5, 473.4, $588.8 \mathrm{mg} / 100 \mathrm{~g}$ for Mozzarella, Minas and Prato cheeses, respectively.

\section{Potassium}

The metabolism of water is affected and myoneural activities are stimulated by $\mathrm{Na}$ as well as $\mathrm{K}$, in the human body. According to nutritional recommendations, the sufficient $\mathrm{Na}$ and $\mathrm{K}$ proportion in diet must be of 0.6 for adults and 0.5 for children (Cruz et al., 2011).

Table 4. The effects of Sirmo, Mendi and Siyabo on K concentrations of herby cheese produced from pasteurized and raw milk in brine and vacuum package during ripening

\begin{tabular}{|c|c|c|c|c|c|c|}
\hline \multirow{2}{*}{\multicolumn{2}{|c|}{$\begin{array}{l}\text { Packaging } \\
\text { Storage } \\
\text { type time }\end{array}$}} & \multicolumn{5}{|c|}{ Treatment } \\
\hline & & A1 & A2 & A3 & A4 & A5 \\
\hline \multirow{4}{*}{ Brine } & 2 & $1124.98 \pm 152.2^{\mathrm{bB}}$ & $890.48 \pm 30.02^{\mathrm{bAB}}$ & $1059.20 \pm 271.59^{\mathrm{bB}}$ & $992.24 \pm 31.94^{\mathrm{cAB}}$ & $642.36 \pm 44.39^{\mathrm{cA}}$ \\
\hline & 30 & $474.88 \pm 58.23^{\mathrm{aA}}$ & $475.31 \pm 107.91^{\mathrm{aA}}$ & $410.84 \pm 3.1^{\mathrm{aA} \alpha}$ & $450.57 \pm 0.71^{\mathrm{bA} \# \alpha}$ & $483.70 \pm 64.63^{\mathrm{bA}}$ \\
\hline & 60 & $422.42 \pm 21.23^{\mathrm{aA}}$ & $384.14 \pm 5.66^{\mathrm{aA}}$ & $390.02 \pm 7.79^{\mathrm{aA} \alpha}$ & $447.76 \pm 18.59^{\mathrm{abA \#}}$ & $444.56 \pm 64.2^{\mathrm{abA}}$ \\
\hline & 90 & $384.69 \pm 5.66^{\mathrm{aA \#}}$ & $367.78 \pm 94.54^{\mathrm{aA}}$ & $309.00 \pm 107.08^{\mathrm{aA}}$ & $396.60 \pm 4.24^{\mathrm{aA \#}}$ & $321.25 \pm 51.88^{\mathrm{aA}}$ \\
\hline \multirow{4}{*}{ Vacuum } & 2 & $1124.98 \pm 152.2^{\mathrm{bB}}$ & $890.48 \pm 30.02^{\mathrm{cAB}}$ & $1059.20 \pm 271.59^{\mathrm{bB}}$ & $992.24 \pm 31.94^{\mathrm{cAB}}$ & $642.36 \pm 44.39^{\mathrm{aA}}$ \\
\hline & 30 & $570.76 \pm 48.91^{\mathrm{aA}}$ & $626.63 \pm 2.88^{\mathrm{bA}}$ & $587.25 \pm 116.72^{\mathrm{aA}}$ & $642.82 \pm 4.03^{\mathrm{bA}}$ & $628.33 \pm 11.53^{\mathrm{aA}}$ \\
\hline & 60 & $555.95 \pm 40.22^{\mathrm{aA}}$ & $622.50 \pm 36.34^{\mathrm{bA}}$ & $497.59 \pm 98.92^{\mathrm{aA}}$ & $625.46 \pm 0.32^{\mathrm{abA}}$ & $611.76 \pm 7.07^{\mathrm{aA}}$ \\
\hline & 90 & $499.50 \pm 4.84^{\mathrm{aAB}}$ & $418.10 \pm 87.89^{\mathrm{aA}}$ & $504.98 \pm 40.13^{\mathrm{aAB}}$ & $581.95 \pm 11.4^{\mathrm{aB}}$ & $605.94 \pm 1.41^{\mathrm{aB} \alpha}$ \\
\hline & & B1 & B2 & B3 & B4 & B5 \\
\hline \multirow{4}{*}{ Brine } & 2 & $758.55 \pm 85.55^{\mathrm{bA}}$ & $914.23 \pm 159.64^{\mathrm{bA}}$ & $791.87 \pm 90.63^{\mathrm{bA}}$ & $650.45 \pm 87.45^{\mathrm{bA}}$ & $799.25 \pm 14.14^{\mathrm{aA}}$ \\
\hline & 30 & $466.96 \pm 16.55^{\mathrm{aAB} \#}$ & $435.83 \pm 75.24^{\mathrm{aA}}$ & $486.75 \pm 4.95^{\mathrm{aAB}}$ & $510.83 \pm 4.17^{\mathrm{aAB}}$ & $535.39 \pm 21.09^{\mathrm{bB}}$ \\
\hline & 60 & $373.15 \pm 123.6^{\mathrm{aA}}$ & $390.57 \pm 44.53^{\mathrm{aA}}$ & $445.62 \pm 7.07^{\mathrm{aA}}$ & $478.45 \pm 42.56^{\mathrm{aA}}$ & $508.18 \pm 32.36^{\mathrm{bA}}$ \\
\hline & 90 & $351.61 \pm 1.41^{\mathrm{aA}}$ & $323.87 \pm 104.81^{\mathrm{aA}}$ & $416.09 \pm 29.32^{\mathrm{aA}}$ & $387.75 \pm 7.71^{\mathrm{aA}}$ & $364.35 \pm 8.61^{\mathrm{aA \#}}$ \\
\hline \multirow{4}{*}{ Vacuum } & 2 & $758.55 \pm 85.55^{\mathrm{bA}}$ & $914.23 \pm 159.64^{\mathrm{bA}}$ & $791.87 \pm 90.63^{\mathrm{cA}}$ & $650.45 \pm 87.45^{\mathrm{bA}}$ & $799.25 \pm 14.14^{\mathrm{bA}}$ \\
\hline & 30 & $579.43 \pm 6.72^{\mathrm{aA}}$ & $594.53 \pm 86.59^{\mathrm{aA}}$ & $716.41 \pm 54.22^{\mathrm{bcA}}$ & $612.98 \pm 36.8^{\mathrm{abA}}$ & $591.21 \pm 66.76^{\mathrm{aA}}$ \\
\hline & 60 & $554.07 \pm 27.89^{\mathrm{aA}}$ & $555.28 \pm 1.9^{\mathrm{aA}}$ & $547.57 \pm 53.44^{\mathrm{abA}}$ & $563.62 \pm 39.39^{\mathrm{abA}}$ & $553.08 \pm 35.54^{\mathrm{aA}}$ \\
\hline & 90 & $515.10 \pm 70.92^{\mathrm{aA}}$ & $419.22 \pm 67.96^{\mathrm{aA}}$ & $525.52 \pm 46.95^{\mathrm{aA}}$ & $476.80 \pm 53.76^{\mathrm{aA}}$ & $507.70 \pm 3.54^{\mathrm{aA}}$ \\
\hline
\end{tabular}

Data values are expressed as means \pm standard deviation. Values in the same column followed by a different letters $(\mathrm{a}-\mathrm{c})$ are significantly different $(P<0.05)$. Values in the same row followed by a different letters $($ A-C) are significantly different $(P<0.05)$. Values in the same column showed different letter $(\alpha)$ between different treatments in the same day and package $(P<0.05)$. Values in the same column showed different letter (\#) between different packages in the same day and package $(P<0.05)$

A1: control cheese manufactured from raw milk, A2: sirmo-added cheese manufactured from raw milk, A3: mendi-added cheese manufactured from raw milk, A4: siyabo-added cheese manufactured from raw milk, A5: sirmo, mendi and siyabo mixture added cheese manufactured from raw milk, B1: control cheese manufactured from pasteurized milk, B2: sirmo-added cheese manufactured from pasteurized milk B3: mendi-added cheese manufactured from pasteurized milk, B4: siyabo-added cheese manufactured from pasteurized milk, B5: sirmo, mendi and siyabo mixture added cheese manufactured from pasteurized milk 
As seen in Table 4, the $\mathrm{K}$ values of herby cheese samples were significantly decreased during the ripening period. The $\mathrm{K}$ values of brine cheeses were determined lower than vacuum packaged cheeses at the end of the storage periods. The possible reason for this situation, the cheese that was ripened in a brine had a higher salt content than the cheese ripened in vacuum packaging. In general, as the salt content increases, the acidity decreases and the $\mathrm{pH}$ value increases in the cheese (Kose, 2015; Almenara et al., 2007). The final average values were lower than those described by Ocak and Kose (2015) and similar with findings obtained by Mendil (2006) for herby cheeses and by Murtaza et al. (2014) for cheddar cheese.

\section{Iron}

Iron is an essential trace element is incorporated as a catalyst in various metabolic reactions. It is a component of hemoglobin, myoglobin, cytochrome and other proteins and plays an important role in the transport, storage and use of oxygen. Milk and dairy products are insufficient source in terms of Fe for human nutrition (Zamberlin et al., 2012). Its deficiency causes anaemia, decrease in immunity and alteration in mental development (Gaucheron, 2000).

Table 5. The effects of Sirmo, Mendi and Siyabo on Fe concentrations of herby cheese produced from pasteurized and raw milk in brine and vacuum package during ripening

\begin{tabular}{|c|c|c|c|c|c|c|}
\hline \multirow{2}{*}{$\begin{array}{l}\text { Packaging } \\
\text { type }\end{array}$} & \multirow{2}{*}{$\begin{array}{l}\text { Storage } \\
\text { time }\end{array}$} & \multicolumn{5}{|c|}{ Treatment } \\
\hline & & A1 & A2 & A3 & A4 & A5 \\
\hline \multirow{4}{*}{ Brine } & 2 & $6.59 \pm 0.13 b^{C \alpha}$ & $5.00 \pm 0.20^{\mathrm{aB}}$ & $4.08 \pm 0.1^{\mathrm{aA} \alpha}$ & $4.19 \pm 0.43^{\mathrm{aA}}$ & $6.04 \pm 0.06^{\mathrm{bC} \alpha}$ \\
\hline & 30 & $5.33 \pm 1^{\mathrm{abA}}$ & $4.89 \pm 0.31^{\mathrm{aA}}$ & $3.76 \pm 0.29^{\mathrm{aA}}$ & $4.11 \pm 0.02^{\mathrm{aA}}$ & $4.89 \pm 1.05^{\mathrm{abA}}$ \\
\hline & 60 & $4.26 \pm 1.44^{\mathrm{abA}}$ & $4.10 \pm 1.05^{\mathrm{aA}}$ & $3.70 \pm 0.71^{\mathrm{aA}}$ & $3.66 \pm 0.66^{\mathrm{aA}}$ & $4.29 \pm 0.73^{\mathrm{abA}}$ \\
\hline & 90 & $3.28 \pm 0.5^{\mathrm{aA}}$ & $3.52 \pm 0.54^{\mathrm{aA}}$ & $3.42 \pm 0.74^{\mathrm{aA}}$ & $3.28 \pm 0.06^{\mathrm{aA}}$ & $3.06 \pm 0.25^{\mathrm{aA}}$ \\
\hline \multirow{4}{*}{ Vacuum } & 2 & $6.59 \pm 0.13^{\mathrm{dC}}$ & $5.00 \pm 0.2^{\mathrm{bB}}$ & $4.08 \pm 0.1^{\mathrm{bA}}$ & $4.19 \pm 0.43^{\mathrm{bA}}$ & $6.04 \pm 0.06^{\mathrm{cC}}$ \\
\hline & 30 & $4.75 \pm 0.07^{\mathrm{cD} \alpha}$ & $4.44 \pm 0.33^{\mathrm{aCD}}$ & $3.78 \pm 0.04^{\mathrm{abA}}$ & $3.84 \pm 0.13^{\mathrm{abAB}}$ & $4.26 \pm 0.08^{\mathrm{bBC}}$ \\
\hline & 60 & $3.79 \pm 0.12^{\mathrm{bB}}$ & $4.37 \pm 0.07^{\mathrm{aC}}$ & $3.61 \pm 0.07^{\mathrm{abAB}}$ & $3.49 \pm 0.19^{\mathrm{abAB}}$ & $3.42 \pm 0.06^{\mathrm{aA}}$ \\
\hline & 90 & $3.19 \pm 0.29^{\mathrm{aA}}$ & $4.27 \pm 0.1^{\mathrm{aB}}$ & $3.44 \pm 0.33^{\mathrm{aAB}}$ & $3.30 \pm 0.35^{\mathrm{aA}}$ & $3.06 \pm 0.49^{\mathrm{aA}}$ \\
\hline & & B1 & B2 & B3 & B4 & B5 \\
\hline \multirow{4}{*}{ Brine } & 2 & $4.39 \pm 0.34^{\mathrm{cA}}$ & $4.89 \pm 0.06^{\mathrm{bAB}}$ & $5.54 \pm 0.08^{\mathrm{dAB}}$ & $5.63 \pm 0.95^{\mathrm{bB}}$ & $5.26 \pm 0.13^{\mathrm{bAB}}$ \\
\hline & 30 & $4.11 \pm 0.08^{\mathrm{bcA} \#}$ & $4.70 \pm 0.28^{\mathrm{bBC}}$ & $4.51 \pm 0.01^{\mathrm{cABC}}$ & $4.47 \pm 0.28^{\mathrm{abAB}}$ & $5.05 \pm 0.19^{\mathrm{bC}}$ \\
\hline & 60 & $3.83 \pm 0.09^{\mathrm{bB}}$ & $4.13 \pm 0.14^{\mathrm{aC}}$ & $3.80 \pm 0.1^{\mathrm{bB}}$ & $3.48 \pm 0.11^{\mathrm{aA}}$ & $3.72 \pm 0.03^{\mathrm{aAB}}$ \\
\hline & 90 & $3.16 \pm 0.02^{\mathrm{aA}}$ & $3.84 \pm 0.07^{\mathrm{aA}}$ & $3.03 \pm 0.43^{\mathrm{aA}}$ & $3.46 \pm 0.19^{\mathrm{aA}}$ & $3.61 \pm 0.49^{\mathrm{aA}}$ \\
\hline \multirow{4}{*}{ Vacuum } & 2 & $4.39 \pm 0.34^{\mathrm{cA}}$ & $4.89 \pm 0.06^{\mathrm{aAB}}$ & $5.54 \pm 0.08^{\mathrm{cAB}}$ & $5.63 \pm 0.95^{\mathrm{bB}}$ & $5.26 \pm 0.13^{\mathrm{bAB}}$ \\
\hline & 30 & $3.51 \pm 0.06^{\mathrm{abA}}$ & $3.99 \pm 0.75^{\mathrm{aA}}$ & $4.45 \pm 0.13^{\mathrm{bA}}$ & $4.02 \pm 0.45^{\mathrm{aA}}$ & $4.50 \pm 0.35^{\mathrm{abA}}$ \\
\hline & 60 & $3.79 \pm 0.04^{\mathrm{bcA}}$ & $3.78 \pm 1.32^{\mathrm{aA}}$ & $3.40 \pm 0.06^{\mathrm{aA}}$ & $3.43 \pm 0.29^{\mathrm{aA}}$ & $3.67 \pm 0.37^{\mathrm{aA}}$ \\
\hline & 90 & $3.06 \pm 0.27^{\mathrm{aA}}$ & $3.65 \pm 0.4^{\mathrm{aA}}$ & $2.97 \pm 0.27^{\mathrm{aA}}$ & $3.29 \pm 0.07^{\mathrm{aA}}$ & $3.51 \pm 0.54^{\mathrm{aA}}$ \\
\hline
\end{tabular}

Data values are expressed as means \pm standard deviation. Values in the same column followed by a different letters $(\mathrm{a}-\mathrm{c})$ are significantly different $(P<0.05)$. Values in the same row followed by a different letters $($ A-C) are significantly different $(P<0.05)$. Values in the same column showed different letter $(\alpha)$ between different treatments in the same day and package $(P<0.05)$. Values in the same column showed different letter (\#) between different packages in the same day and package $(P<0.05)$

A1: control cheese manufactured from raw milk, A2: sirmo-added cheese manufactured from raw milk, A3: mendi-added cheese manufactured from raw milk, A4: siyabo-added cheese manufactured from raw milk, A5: sirmo, mendi and siyabo mixture added cheese manufactured from raw milk, B1: control cheese manufactured from pasteurized milk, B2: sirmo-added cheese manufactured from pasteurized milk B3: mendi-added cheese manufactured from pasteurized milk, B4: siyabo-added cheese manufactured from pasteurized milk, B5: sirmo, mendi and siyabo mixture added cheese manufactured from pasteurized milk 


\section{Zinc}

Zinc is an essential mineral that is very nutritionally for human and deficiency creates significant implications for human health. The deficiency of $\mathrm{Zn}$ results in a wide spectrum. Its clinical effects depending on age, stage of development and deficiencies of related metals (Bakircioglu et al., 2011). The maximum tolerable daily intake of $\mathrm{Zn}$ is $60 \mathrm{mg}$ (FAO/WHO, 1999, 1999). In this study, the content of Zn for herby cheeses in brine and vacuum packages were lower than the WHO's values.

Table 6. The effects of Sirmo, Mendi and Siyabo on Zn concentrations of herby cheese produced from pasteurized and raw milk in brine and vacuum package during ripening

\begin{tabular}{|c|c|c|c|c|c|c|}
\hline \multirow{2}{*}{$\begin{array}{l}\text { Packaging } \\
\text { type }\end{array}$} & \multirow{2}{*}{$\begin{array}{l}\text { Storage } \\
\text { time }\end{array}$} & \multicolumn{5}{|c|}{ Treatment } \\
\hline & & A1 & A2 & A3 & A4 & A5 \\
\hline \multirow{4}{*}{ Brine } & 2 & $16.65 \pm 0.86^{\mathrm{aB}}$ & $14.63 \pm 0.13^{\mathrm{bAB}}$ & $14.87 \pm 0.08^{\mathrm{bAB}}$ & $16.67 \pm 1.34^{\mathrm{cB}}$ & $14.12 \pm 1.32^{\mathrm{bA}}$ \\
\hline & 30 & $16.03 \pm 0.87^{\mathrm{aB}}$ & $14.50 \pm 0.24^{\mathrm{bAB}}$ & $14.76 \pm 0.27^{\mathrm{bAB}}$ & $15.67 \pm 0.95^{\mathrm{bcB}}$ & $13.91 \pm 0.17^{\mathrm{bA}}$ \\
\hline & 60 & $14.95 \pm 0.23^{\mathrm{aB}}$ & $14.16 \pm 0.52^{\mathrm{abAB}}$ & $14.25 \pm 0.66^{\mathrm{abAB}}$ & $13.48 \pm 0.42^{\mathrm{abA \#}}$ & $13.24 \pm 0.01^{\mathrm{abA}}$ \\
\hline & 90 & $13.71 \pm 2.58^{\mathrm{aA}}$ & $13.63 \pm 0.16^{\mathrm{aA}}$ & $13.49 \pm 0.13^{\mathrm{aA}}$ & $11.36 \pm 0.08^{\mathrm{aA} \#}$ & $11.28 \pm 0.88^{\mathrm{aA}}$ \\
\hline \multirow{4}{*}{ Vacuum } & 2 & $16.65 \pm 0.86^{\mathrm{aB}}$ & $14.63 \pm 0.13^{\mathrm{aAB}}$ & $14.87 \pm 0.08^{\mathrm{aAB}}$ & $16.67 \pm 1.34^{\mathrm{aB}}$ & $14.12 \pm 1.32^{\mathrm{aA}}$ \\
\hline & 30 & $16.36 \pm 0.5^{\mathrm{aB}}$ & $14.45 \pm 0.19^{\mathrm{aA}}$ & $14.42 \pm 0.62^{\mathrm{aA}}$ & $16.02 \pm 0.84^{\mathrm{aB}}$ & $13.94 \pm 0.07^{\mathrm{aA}}$ \\
\hline & 60 & $16.05 \pm 0.31^{\mathrm{aC}}$ & $14.16 \pm 0.13^{\mathrm{aB}}$ & $13.87 \pm 0.19^{\mathrm{aAB}}$ & $15.89 \pm 0.28^{\mathrm{aC}}$ & $13.42 \pm 0.33^{\mathrm{aA}}$ \\
\hline & 90 & $15.79 \pm 0.34^{\mathrm{aC} \alpha}$ & $13.93 \pm 0.65^{\mathrm{aAB}}$ & $13.69 \pm 0.59^{\mathrm{aAB}}$ & $14.59 \pm 0.16^{\mathrm{aB}}$ & $13.04 \pm 0.05^{\mathrm{aA}}$ \\
\hline & & B1 & B2 & B3 & B4 & B5 \\
\hline \multirow{4}{*}{ Brine } & 2 & $15.61 \pm 1.84^{\mathrm{aA}}$ & $14.75 \pm 2.09^{\mathrm{aA}}$ & $15.65 \pm 1.69^{\mathrm{bA}}$ & $16.59 \pm 1.99^{\mathrm{aA}}$ & $16.58 \pm 0.19^{\mathrm{bA}}$ \\
\hline & 30 & $14.22 \pm 3.1^{\mathrm{aA}}$ & $15.00 \pm 0.53^{\mathrm{aA}}$ & $14.68 \pm 0.95^{\mathrm{abA}}$ & $15.11 \pm 4.08^{\mathrm{aA}}$ & $15.32 \pm 1.94^{\mathrm{abA}}$ \\
\hline & 60 & $13.54 \pm 1.61^{\mathrm{aA}}$ & $14.92 \pm 0.86^{\mathrm{aA}}$ & $14.47 \pm 0.86^{\mathrm{abA}}$ & $14.93 \pm 0.04^{\mathrm{aA}}$ & $13.87 \pm 1.02^{\mathrm{abA}}$ \\
\hline & 90 & $12.36 \pm 0.96^{\mathrm{aAB}}$ & $13.99 \pm 0.28^{\mathrm{aB}}$ & $12.20 \pm 0.28^{\mathrm{aA \#}}$ & $13.31 \pm 0.41^{\mathrm{aAB} \#}$ & $12.22 \pm 0.96^{\mathrm{aAB}}$ \\
\hline \multirow{4}{*}{ Vacuum } & 2 & $15.61 \pm 1.84^{\mathrm{aA}}$ & $14.75 \pm 2.09^{\mathrm{aA}}$ & $15.65 \pm 1.69^{\mathrm{aA}}$ & $16.59 \pm 1.99^{\mathrm{aA}}$ & $16.58 \pm 0.19^{\mathrm{aA}}$ \\
\hline & 30 & $15.53 \pm 1.38^{\mathrm{aA}}$ & $14.54 \pm 0.07^{\mathrm{aA}}$ & $15.50 \pm 0.31^{\mathrm{aA}}$ & $16.41 \pm 0.49^{\mathrm{aA}}$ & $16.16 \pm 0.80^{\mathrm{aA}}$ \\
\hline & 60 & $15.25 \pm 0.19^{\mathrm{aA}}$ & $14.34 \pm 0.15^{\mathrm{aA}}$ & $15.35 \pm 0.76^{\mathrm{aA}}$ & $15.80 \pm 0.84^{\mathrm{aA}}$ & $15.25 \pm 1.10^{\mathrm{aA}}$ \\
\hline & 90 & $12.96 \pm 0.34^{\mathrm{aA}}$ & $14.13 \pm 0.37^{\mathrm{aB}}$ & $15.36 \pm 0.05^{\mathrm{aC}}$ & $15.09 \pm 0.34^{\mathrm{aC}}$ & $14.93 \pm 0.31^{\mathrm{aC}}$ \\
\hline
\end{tabular}

Data values are expressed as means \pm standard deviation. Values in the same column followed by a different letters $(\mathrm{a}-\mathrm{c})$ are significantly different $(P<0.05)$. Values in the same row followed by a different letters $(\mathrm{A}-\mathrm{C})$ are significantly different $(P<0.05)$. Values in the same column showed different letter $(\alpha)$ between different treatments in the same day and package $(P<0.05)$. Values in the same column showed different letter (\#) between different packages in the same day and package $(P<0.05)$

A1: control cheese manufactured from raw milk, A2: sirmo-added cheese manufactured from raw milk, A3: mendi-added cheese manufactured from raw milk, A4: siyabo-added cheese manufactured from raw milk, A5: sirmo, mendi and siyabo mixture added cheese manufactured from raw milk, B1: control cheese manufactured from pasteurized milk, B2: sirmo-added cheese manufactured from pasteurized milk B3: mendi-added cheese manufactured from pasteurized milk, B4: siyabo-added cheese manufactured from pasteurized milk, B5: sirmo, mendi and siyabo mixture added cheese manufactured from pasteurized milk

The $\mathrm{Zn}$ concentration of herby cheeses produced from raw and pasteurized milk changed from 11.28 to $16.67,12.96$ to $16.59 \mathrm{mg} / \mathrm{kg}$, respectively. It has been found that the $\mathrm{Zn}$ concentration of cheese produced from both pasteurized and raw milk decreased during the storage period. But, at the end of the storage periods, the $\mathrm{Zn}$ content of brine cheeses were found lower than vacuum packaged cheeses. When the findings are compared with the literature, our results were lower than the value determined by Oksuztepe et al. (2013) as $20.50 \mathrm{mg} / \mathrm{kg}$ for white cheese, by Isleten et al. (2007) as $2.12-8.19 \mathrm{mg} / 100 \mathrm{~g}$ for Ezine cheese, by Cichoscki et al. (2002) as 29.21-36.60 mg/kg 
for Prato cheese, by Altun and Kose (2016) as 22.70 to 65.37 for Kelle cheese, by Bilandzic et al. (2015) as $46 \mathrm{mg} / \mathrm{kg}$ for semi hard fat cheese consumed in Croatia.

\section{Manganese}

The Institute of Medicine suggests that intake of Mn should not exceed the tolerable daily maximum limit of $11 \mathrm{mg} /$ day (National Research Council, 1989). In this study, Mn concentrations of cheese samples changed from 0.70 to $0.26 \mathrm{mg} / \mathrm{kg}$. The content of Mn for Herby cheese samples in brine and vacuum packages were lower than the National Research Council.

Table 7. The effects of Sirmo, Mendi and Siyabo on Mn concentrations of herby cheese produced from pasteurized and raw milk in brine and vacuum package during ripening

\begin{tabular}{|c|c|c|c|c|c|c|}
\hline \multirow{2}{*}{$\begin{array}{l}\text { Packaging } \\
\text { time }\end{array}$} & \multirow{2}{*}{$\begin{array}{l}\text { Storage } \\
\text { type }\end{array}$} & \multicolumn{5}{|c|}{ Treatment } \\
\hline & & A1 & A2 & $\mathbf{A 3}$ & A4 & A5 \\
\hline \multirow{4}{*}{ Brine } & 2 & $0.52 \pm 0.11^{\mathrm{bA}}$ & $0.70 \pm 0.08^{\mathrm{bB}}$ & $0.46 \pm 0.06^{\mathrm{aA}}$ & $0.59 \pm 0.04^{\mathrm{cAB}}$ & $0.43 \pm 0.01^{\mathrm{aA}}$ \\
\hline & 30 & $0.50 \pm 0.03^{\mathrm{abA}}$ & $0.46 \pm 0.01^{\mathrm{aA}}$ & $0.39 \pm 0.16^{\mathrm{aA}}$ & $0.38 \pm 0.01^{\mathrm{bA}}$ & $0.39 \pm 0.01^{\mathrm{aA}}$ \\
\hline & 60 & $0.37 \pm 0.04^{\mathrm{abA}}$ & $0.37 \pm 0.01^{\mathrm{aA}}$ & $0.35 \pm 0.01^{\mathrm{aA} \alpha}$ & $0.34 \pm 0.01^{\mathrm{abA}}$ & $0.38 \pm 0.02^{\mathrm{aA}}$ \\
\hline & 90 & $0.34 \pm 0.04^{\mathrm{aA}}$ & $0.33 \pm 0.03^{\mathrm{aA}}$ & $0.33 \pm 0.00^{\mathrm{aA}}$ & $0.31 \pm 0.00^{\mathrm{aA}}$ & $0.33 \pm 0.13^{\mathrm{aA}}$ \\
\hline \multirow{4}{*}{ Vacuum } & 2 & $0.52 \pm 0.11^{\mathrm{bA}}$ & $0.70 \pm 0.08^{\mathrm{bB}}$ & $0.46 \pm 0.06^{\mathrm{bA}}$ & $0.59 \pm 0.04^{\mathrm{bAB}}$ & $0.43 \pm 0.01^{\mathrm{bA}}$ \\
\hline & 30 & $0.37 \pm 0.01^{\mathrm{abA}}$ & $0.46 \pm 0.04^{\mathrm{aAB}}$ & $0.44 \pm 0.05^{\mathrm{bAB}}$ & $0.51 \pm 0.06^{\mathrm{bB}}$ & $0.40 \pm 0.02^{\mathrm{bAB}}$ \\
\hline & 60 & $0.36 \pm 0.04^{\mathrm{abA}}$ & $0.40 \pm 0.07^{\mathrm{aA}}$ & $0.30 \pm 0.01^{\mathrm{aA}}$ & $0.39 \pm 0.01^{\mathrm{aA}}$ & $0.36 \pm 0.03^{\mathrm{abA}}$ \\
\hline & 90 & $0.34 \pm 0.01^{\mathrm{aAB}}$ & $0.38 \pm 0.01^{\mathrm{aB} \alpha}$ & $0.31 \pm 0.01^{\mathrm{aA}}$ & $0.37 \pm 0.01^{\mathrm{aB}}$ & $0.30 \pm 0.03^{\mathrm{aA}}$ \\
\hline & & B1 & B2 & B3 & B4 & B5 \\
\hline \multirow{4}{*}{ Brine } & 2 & $0.42 \pm 0.05^{\mathrm{aA}}$ & $0.42 \pm 0.06^{\mathrm{bA}}$ & $0.51 \pm 0.11^{\mathrm{bA}}$ & $0.55 \pm 0.02^{\mathrm{bA}}$ & $0.46 \pm 0.08^{\mathrm{aA}}$ \\
\hline & 30 & $0.39 \pm 0.00^{\mathrm{aA}}$ & $0.36 \pm 0.04^{\mathrm{abA}}$ & $0.31 \pm 0.01^{\mathrm{aA}}$ & $0.35 \pm 0.11^{\mathrm{abA}}$ & $0.42 \pm 0.13^{\mathrm{aA}}$ \\
\hline & 60 & $0.35 \pm 0.02^{\mathrm{aAB}}$ & $0.36 \pm 0.01^{\mathrm{abB}}$ & $0.31 \pm 0.01^{\mathrm{aA}}$ & $0.33 \pm 0.01^{\mathrm{abAB}}$ & $0.34 \pm 0.02^{\mathrm{aAB}}$ \\
\hline & 90 & $0.33 \pm 0.05^{\mathrm{aA}}$ & $0.26 \pm 0.00^{\mathrm{aA}}$ & $0.30 \pm 0.06^{\mathrm{aA}}$ & $0.28 \pm 0.10^{\mathrm{aA}}$ & $0.35 \pm 0.01^{\mathrm{aA}}$ \\
\hline \multirow{4}{*}{ Vacuum } & 2 & $0.42 \pm 0.05^{\mathrm{aA}}$ & $0.42 \pm 0.06^{\mathrm{aA}}$ & $0.51 \pm 0.11^{\mathrm{aA}}$ & $0.55 \pm 0.02^{\mathrm{bA}}$ & $0.46 \pm 0.08^{\mathrm{aA}}$ \\
\hline & 30 & $0.39 \pm 0.01^{\mathrm{aAB}}$ & $0.38 \pm 0.01^{\mathrm{abA}}$ & $0.40 \pm 0.02^{\mathrm{aAB}}$ & $0.40 \pm 0.03^{\mathrm{aAB}}$ & $0.44 \pm 0.02^{\mathrm{aB}}$ \\
\hline & 60 & $0.34 \pm 0.01^{\mathrm{aA}}$ & $0.36 \pm 0.02^{\mathrm{abA}}$ & $0.37 \pm 0.03^{\mathrm{aA}}$ & $0.38 \pm 0.01^{\mathrm{aA}}$ & $0.39 \pm 0.05^{\mathrm{aA}}$ \\
\hline & 90 & $0.32 \pm 0.05^{\mathrm{aA}}$ & $0.30 \pm 0.01^{\mathrm{aA}}$ & $0.34 \pm 0.06^{\mathrm{aA}}$ & $0.38 \pm 0.04^{\mathrm{aA}}$ & $0.38 \pm 0.01^{\mathrm{aA}}$ \\
\hline
\end{tabular}

Data values are expressed as means \pm standard deviation. Values in the same column followed by a different letters $(\mathrm{a}-\mathrm{c})$ are significantly different $(P<0.05)$. Values in the same row followed by a different letters $(\mathrm{A}-\mathrm{C})$ are significantly different $(P<0.05)$. Values in the same column showed different letter $(\alpha)$ between different treatments in the same day and package $(P<0.05)$. Values in the same column showed different letter (\#) between different packages in the same day and package $(P<0.05)$

A1: control cheese manufactured from raw milk, A2: sirmo-added cheese manufactured from raw milk, A3: mendi-added cheese manufactured from raw milk, A4: siyabo-added cheese manufactured from raw milk, A5: sirmo, mendi and siyabo mixture added cheese manufactured from raw milk, B1: control cheese manufactured from pasteurized milk, B2: sirmo-added cheese manufactured from pasteurized milk B3: mendi-added cheese manufactured from pasteurized milk, B4: siyabo-added cheese manufactured from pasteurized milk, B5: sirmo, mendi and siyabo mixture added cheese manufactured from pasteurized milk

Decrease in the Mn concentrations of pasteurized and raw milk herby cheeses were determined during the ripening period. The possible decrease in $\mathrm{pH}$ can induce this situation. In general, Mn are linked to the insoluble fraction of casein micelle of milk in a ratio of $95 \%$ (Cichoscki et al., 2002). However, as the $\mathrm{pH}$ in cheese decreases during ripening, migration of $\mathrm{Mn}$ towards the soluble fraction is monitored (Macedo and Malcata, 1997). As a result, the loss of Mn content occurs in brine or vacuum packaged 
samples. Our results showed similar behaviour with findings obtained by Cichoscki et al. (2002) as 0.36 to $0.26 \mathrm{mg} / \mathrm{kg}$ for Prato cheese, were higher than the value determined by Kirdar et al. (2015) as 0.11 to $0.19 \mu \mathrm{g} / \mathrm{g}$ for Kargi Tulum Cheese and were lower than the value determined by Macedo and Malcata (1997) as 1.17 to $1.40 \mathrm{mg} / \mathrm{kg}$ for Serra cheese.

\section{Conclusions}

As a result, $\mathrm{Na}, \mathrm{Ca}, \mathrm{K}, \mathrm{Mg}, \mathrm{Zn}, \mathrm{Fe}$ and $\mathrm{Mn}$ content of cheese samples were influenced by herbs, packaging, ripening and heat treatment. It was observed that ripening has the most pronounced effect on studied variables. The concentrations of minerals in cheese samples decreased and the changes of ratios of mineral compounds were different during storage period. The vacuum packaged cheeses were found to have a higher mineral content than the cheeses stored in brine at the end of 90 days. Because of the mineral loss of cheeses in brine were higher than in vacuum packaged due to diffusions of mineral substances from cheese into the brine during maturation. This investigation is first study comparing herbs species, packaging type and ripening period on the mineral content of herby cheeses produced from pasteurized and raw milk. Therefore, further investigations are needed to determine the influence of various factors on the mineral compositions of herby cheeses.

\section{REFERENCES}

[1] Agarwal, S., McCoy, D., Graves, V., Gerard, P. D., Clark, S. (2011): Sodium content in retail Cheddar. Mozzarella and process cheeses varies considerably in the United States. Journal of Dairy Science 94: 1605-1615.

[2] Almenara, F., Alvarez, S., Darias, J., Rodriguez, E., Diaz, C., Fresno, M. (2007): Effect of the ripening in the mineral composition of the cheese made with Majorera goat's milk. - Archivos de Zootecnia 56(1): 667-671.

[3] Altun, I., Kose, S. (2016): Determination of some properties of traditional Kelle cheese. Yuzuncu Yil University Journal of Agricultural Sciences 26(4): 642-647 (in Turkish).

[4] Andic, S., Genccelep, H., Kose, S. (2010): Determination of biogenic amines in Herby cheese. - International Journal of Food Properties 13: 1300-1314.

[5] Andic, S., Tuncturk, Y., Javidipour, I., Genccelep, H. (2015): Effect of different herbs on biogenic amine contents and some characteristics of herby cheese. - Gida 40(1): 1-8.

[6] Bakircioglu, D., Bakircioglu Kurtulus, Y., Ucar, G. (2011): Determination of some traces metal levels in cheese samples packaged in plastic and tin containers by ICP-OES after dry, wet and microwave digestion. - Food and Chemical Toxicology 49: 202-207.

[7] Bilandzic, N., Sedak, M., Dokic', M., Bozic, D., Vrbic, A. (2015): Content of macro and microelements and evaluation of the intake of different dairy products consumed in Croatia. - Journal of Food Composition and Analysis 40: 143-147.

[8] Cichoscki, A. J., Valduga, E., Valduga, A. T., Tornadijo, M. E., Fresno, J. M. (2002): Characterization of Prato cheese, a Brazilian semi-hard cow variety: evolution of physico-chemical parameters and mineral composition during ripening. - Food Control 13: 329-336.

[9] Cruz, A. G., Faria, J. A. F., Pollonio, M. A. R., Bolini, H. M. A., Celeghini, R. M. S., Granato, D., Shah, N. P. (2011): Cheeses with reduced content: Effects on functionality, public health benefits and sensory properties. - Trends in Food Science \& Technology 22: $276-291$. 
[10] Cetinkaya, A., Akbaba, G. B., Ozcakmak, S., Gulbaz, G. (2016): Mineral and heavy metal content in Cami Bogazi cheese on sale in Trabzon, Turkey. - Gida 41(5): 317-321 (in Turkish).

[11] FAO/WHO (1999): Joint FAO/WHO foods standards programme. Expert committee on the food additives, summary and conclusions. - 53rd Meeting, June 1-10. FAO, Rome.

[12] Gaucheron, F. (2000): Iron fortification in dairy industry. - Trends in Food ScienceTechnology 11: 403-409.

[13] Gider, K. (2006): Determination of Some Factors that Affects Salt Immigration in White Cheese. - Selcuk University Graduate School of Natural and Applied Sciences Department of Food Engineering, Konya.

[14] Guinee, T. P., Fox, P. F. (1986): Transport of sodium chloride and water in Romano cheese slices during brining. - Food Chemistry 19: 49-64.

[15] Hayaloglu, A. A., Fox, P. F. (2008): Cheeses of Turkey: 3. Varieties containing herbs or spices. - Dairy Science and Technology 88: 245-256.

[16] Felicio, T. L., Esmerino, E. A., Cruz, A. G., Nogueira, L. C., Raices, R. S. L., Deliza, R., Bolini, H. M. A., Pollonio, M. A. R. (2013): Cheese. What is its contribution to the sodium intake of Brazilians? - Appetite 66: 84-88.

[17] Holland, B., Welch, A. A., Unwin, I. D., Buss, D. H., Paul, A. A., Southgate, D. A. T. (1995): The Composition of Foods. 5th Ed. - Royal Society of Chemistry and Ministry of Agriculture, Fisheries and Food, London.

[18] IDF (International Dairy Federetaion). (1992): Trace Elements in Milk and Milk Products. - Bulletin of the International Dairy Federation, No: 278, Brussels.

[19] Isleten, M., Uysal-Pala, C., Karagul-Yuceer, Y. (2007): Mineral content of Ezine cheese. - The Journal of Food 32(4): 173-179 (in Turkish).

[20] Kirdar, S. S., Ocak, E., Kose, S. (2013): Mineral and trace metal levels of Akcakatik cheese collected from Mediterranean region-Turkey. - Asian Journal of Chemistry 25: 1643-1646. DOI: 10.14233/ajchem.2013.13611.

[21] Kirdar, S. S., Kose, S., Gun, I., Ocak, E., Kursun, O. (2015): Do consumption of Karg1 Tulum cheese meet daily requirements for minerals and trace elements? Mljekarstvo 65(3): 203-209.

[22] Kose, S. - (2015): The effect of some herbs added to herby cheese on antimicrobial properties, antioxidant capacity and phenolic compounds of cheese. - PhD Thesis. Yuzuncu Yil University Department of Food Engineering, Van (in Turkish).

[23] Kose, S., Ocak, E. (2015): Determination of some characteristic properties of traditional Surk cheese. - Academic Food Journal 13(2): 135-139 (in Turkish).

[24] Macedo, A. C., Malcata, F. X. (1997): Changes of mineral concentrations in Serra cheese during ripening and throughout the cheesemaking season. - Journal of the Science of Food and Agriculture 74: 409-415.

[25] Mendil, D. (2006): Mineral and trace metal levels in some cheese collected from Turkey. - Food Chemistry 96: 532-537.

[26] Murtaza, M. A., Huma, N., Sameen, A., Saeed, M., Murtaza, M. S. (2014): Minerals and lactic acid contents in buffalo milk cheddar cheese; a comparison with cow. - Journal of Food and Nutrition Research 2(8): 465-468.

[27] National Research Council (1989): Recommended Dietary Allowances. 10th ed. National Academic Press, Washington, DC.

[28] Ocak, E., Kose, S. (2015): Production of Van Herby cheese and Its mineral content. The Journal of Food 40(6): 343-348 (in Turkish).

[29] Ozlu, H., Aydemir-Atasever, M., Urcar, S., Atasever, M. (2012): Mineral contents and heavy metal contamiantion in Kashar cheeses consumed in Erzurum province, Turkey. Journal of the Faculty of Veterinary Medicine, Kafkas University 18(2): 205-208 (in Turkish). 
[30] Oksuztepe, G., Karatepe, P., Ozcelik, M., Incili, G. K. (2013): Mineral substances and heavy metal contents in Tulum cheese and fresh White cheese. - Frrat University Health Sciences Veterinary Journal 27(2): 93-97 (in Turkish).

[31] Sagun, E., Tarakci, Z., Sancak, H., Durmaz, H. (2005): Change of mineral content in pickled Herby cheese during ripening. - Van Veterinary Journal 16(1): 21-25 (in Turkish).

[32] Tarakci, Z., Akyuz, N. (2009): Effects of packaging materials and filling methods on selected characteristics of Otlu (Herby) cheese. - International Journal of Food Properties 12(3): 496-511. DOI: 10.1080/10942910701813941.

[33] Tarakci, Z., Kucukoner, E. (2008): Comparison of basic nutrients, mineral and heavy metal contents of herby dairy products. - International Journal of Food Science and Technology 43: 216-219.

[34] Tarakci, Z., Temiz, H. (2009): A review of the chemical, biochemical and antimicrobial aspects of Turkish Otlu (herby) cheese. - International Journal of Dairy Technology 62(3): 354-360.

[35] Tarakci, Z., Coskun, H., Tuncturk, Y. (2004): Some properties of fresh and ripened herby cheese, a traditional variety produced in Turkey. - Food Technology and Biotechnology 42(1): 47-50.

[36] Tarakci, Z., Sancak, H., Durmaz, H., Kilicel, F. (2005): Mineral substances and heavy metal contents of herby cheeses. - Van Health Sciences Journal 8: 18-23 (in Turkish).

[37] Tuncturk, Y., Ocak, E., Kose, S. (2014): Changes in chemical and physical properties and proteolysis of Van herby (otlu) cheese during ripening. - The Journal of Food 39(3): 163 170 (in Turkish).

[38] Yuzbasi, N., Sezgin, E., Yıldırım, M., Yıldırım, Z. (2003): Survey of lead, cadmium, iron, copper and zinc in Kashar cheese. - Food Additives and Contaminants 20: 464-469. DOI: $10.1080 / 0265203031000094654$.

[39] Zamberlin, S., Antunac, N., Havranek, J., Samaržija, D. (2012): Mineral elements in milk and dairy products. - Mljekarstvo 62(2): 111-125. 